\title{
Kadar kalsium serum pada anak stunting dan tidak stunting usia 24-59 bulan
}

Calcium serum level of stunting and non stunting children aged 24-59 months

Yulinda Kurniasari ${ }^{1}$, Mohammad Juffrie ${ }^{2}$, Mei Neni Sitaresmi ${ }^{2}$, Muhammad Dawam Jamil ${ }^{4}$

${ }^{1}$ Minat Utama Gizi dan Kesehatan, Program Studi S2 Ilmu Kesehatan Masyarakat Fakultas Kedokteran Universitas Gadjah Mada

${ }^{2}$ Departemen Ilmu Kesehatan Anak, Fakultas Kedokteran Universitas Gadjah Mada

${ }^{3}$ Jurusan Gizi Politeknik Kesehatan Kementerian Kesehatan Yogyakarta

\begin{abstract}
Background: Children with stunting as the accumulations of the lack of nutrient or continuous infection are highly at risk to suffer from illness and death. In developing country, there are 165 million children under the age of suffering from stunting. Research done showed that nationally stunting prevalence in 2013 is 37,2\%. West Borneo is one of the twenty provinces with the stunting prevalence above the national average. During growth period, children need calcium especially for ossification. The lack of calcium is mainly caused by inadequate intake and or non-optimal calcium absorption. Some of previous research has showed that the level of calcium serum of children with stunting has significantly lowered than the normal children. Objective: The aim of this study was to analyse the calcium serum level of the children with stunting aged of 24-59 months in Pontianak City. Method: This study is a cross sectional design. It conducted in East Pontianak and North Pontianak subdistricts. Number of samples was 90 childrens. Statistical analysis was performed using Chi-Square, $t$-test, and logistic regression. Results: There was no significance in serum calcium level between stunting and non stunting children $(p=0,193)$. The average of the calcium serum level of the

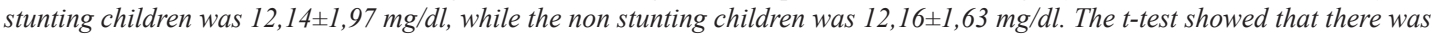
no significant difference $(p=0,966)$. Conclusion: There is no significant difference of the calcium serum level between the stunting and non stunting children aged of 24- 59 months in Pontianak City ( $p=0,193)$.
\end{abstract}

KEY WORDS: calcium serum; children aged 24- 59 months; stunting

\section{ABSTRAK}

Latar belakang: Anak penderita stunting sebagai akibat dari kekurangan gizi atau infeksi secara berulang cenderung berisiko lebih besar untuk menderita penyakit dan mengalami kematian. Di negara berkembang, terdapat sekitar 165 juta balita mengalami stunting. Hasil Riskesdas tahun 2013 menunjukkan bahwa prevalensi nasional stunting sebesar 37,2\%. Kalimantan Barat merupakan salah satu dari 20 provinsi dengan angka stunting di atas prevalensi nasional. Selama masa pertumbuhan, kalsium diperlukan terutama untuk proses pertumbuhan tulang. Beberapa penelitian terdahulu telah menunjukkan bahwa kadar kalsium serum pada anak-anak stunting secara bermakna lebih rendah dibandingkan dengan anak normal. Tujuan: Menganalisis kadar kalsium serum pada anak stunting dan tidak stunting usia 24-59 bulan di Kota Pontianak. Metode: Penelitian ini menggunakan desain cross sectional, dilaksanakan di Kecamatan Pontianak Timur dan Kecamatan Pontianak Utara dengan jumlah sampel terdiri dari 90 anak. Analisis statistik dilakukan dengan uji Chi-Square, t-test, dan regresi logistik. Hasil: Kategori kadar kalsium serum secara statistik tidak memiliki perbedaan yang bermakna pada anak stunting dan tidak stunting $(\mathrm{p}=0,193)$. Rerata kadar kalsium serum pada anak

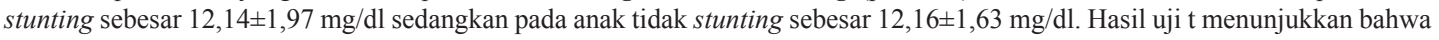
tidak ada perbedaan yang bermakna $(\mathrm{p}=0,966)$. Simpulan: Tidak ada perbedaan yang bermakna antara kadar kalsium serum pada anak stunting dan tidak stunting $(\mathrm{p}=0,193)$ usia $24-59$ bulan di Kota Pontianak.

KATA KUNCI: kalsium serum; anak 24-59 bulan; stunting

Korespondensi: Yulinda Kurniasari, Minat Utama Gizi dan Kesehatan, Program Studi S2 Ilmu Kesehatan Masyarakat Fakultas Kedokteran Universitas Gadjah Mada, Jl. Farmako, Sekip Utara Yogyakarta 55281,e-mail: yulinda.kurniasari@mail.ugm.ac.id 


\section{PENDAHULUAN}

Pertumbuhan linear anak usia dini dianggap sebagai penanda pertumbuhan yang berkaitan dengan risiko kesakitan dan kematian jangka pendek, kejadian penyakit tidak menular ketika dewasa, penurunan kemampuan belajar dan rendahnya produktivitas (1). Seorang anak dikatakan apabila tinggi badan menurut usia berada di bawah -2 SD menurut standar baku rujukan pertumbuhan anak (2). Terdapat 165 juta anak di bawah lima tahun mengalami. Target global adalah menurunkan sebanyak 40\% pada tahun 2025 (3). Hasil Riset kesehatan dasar (Riskesdas) menunjukkan prevalensi secara nasional tahun 2013 sebesar 37,2\%. Prevalesi tersebut meningkat dari prevalensi nasional tahun 2010 (35,6\%) dan tahun 2007 (36,8\%) (4). Prevalensi tertinggi berada pada anak usia 24-59 bulan (5).

Faktor-faktor penyebab sangat kompleks dan multifaktorial, antara lain genetik, sosial ekonomi, pendidikan dan pengetahuan orang tua, serta jumlah keluarga yang banyak (6). Potensi genetik dan pemberian zat gizi yang optimal merupakan penentu utama pertumbuhan tulang pada anak (7). Setelah lahir, matriks tulang mengalami proses kalsifikasi, karena kalsium merupakan mineral utama dalam ikatan ini, keduanya harus berada dalam jumlah yang cukup di dalam cairan yang mengelilingi matriks tulang (8). Kekurangan kalsium pada anak dapat mengakibatkan (9). Adaptasi pembentukan tulang dikendalikan oleh hormon pertumbuhan, hormon tiroid, kalsitonin, hormon paratiroid (PTH), dan hormon kelamin, serta kalsium, fosfor, vitamin A, dan vitamin D (10).

Kalimantan Barat merupakan salah satu dari 20 provinsi dengan angka di atas prevalensi nasional. Berdasarkan hasil Riskesdas tahun 2013, prevalensi di Kalimantan Barat sebesar 38,6\%. Prevalensi balita di Kota Pontianak pada tahun 2014 sebanyak 17,72\%. Prevalensi tertinggi terdapat di Kecamatan Pontianak Timur yaitu sebesar 26,94\% dan diikuti Kecamatan Pontianak Utara sebesar 25,56 \% (4). Mengingat bahwa belum pernah dilakukan penelitian serupa di wilayah Indonesia termasuk Kalimantan Barat, maka penelitian ini penting untuk dilakukan dengan tujuan untuk menganalisis kadar kalsium serum pada anak dan tidak usia 24-59 bulan di Kota Pontianak.

\section{BAHAN DAN METODE}

Jenis penelitian ini adalah observasional analitik dengan metode kuantitatif. Desain yang digunakan adalah cross sectional yang dilaksanakan di Kecamatan Pontianak Timur dan Kecamatan Pontianak Utara pada bulan Juli-Agustus 2015. Izin penelitian dan kelaikan etik diperoleh dari Komite Etik Penelitian Kesehatan dan Kedokteran (MHREC) Universitas Gadjah Mada dengan nomor surat KE/FK/953/EC/2015. Subjek penelitian merupakan seluruh anak berusia 24-59 bulan yang bertempat tinggal di lokasi penelitian dengan memenuhi kriteria inklusi. Kriteria inklusi yaitu orang tua atau pengasuh menyetujui anaknya dilibatkan dalam penelitian dan bersedia menandatangani informed consent serta anak memiliki data tanggal lahir dan berat badan lahir. Kriteria eksklusi yaitu anak menderita penyakit berat (penyakit kelenjar paratiroid, penyakit ginjal dan kanker), kelainan kongenital (penyakit jantung bawaan), cacat fisik, dan infeksi kronis (TBC).

Perhitungan besar sampel yang dibutuhkan dalam penelitian ini dihitung menggunakan rumus besar sampel dengan tingkat kepercayaan (95\%); proporsi (P) berdasarkan prevalensi balita stunting di Kecamatan Pontianak Timur dan Pontianak Utara (2014) sebesar $27 \%$; dan derajat ketepatan pendugaan besar sampel (d) sebesar 10\% sehingga jumlah sampel minimal yang dibutuhkan pada penelitian adalah sebanyak 77 anak dan ditambah $10 \%$ menjadi total sampel sebanyak 90 anak. Pengumpulan data dilakukan melalui kegiatan Posyandu dan juga mendatangi rumah subjek. Jumlah sampel total sebesar 90 responden (37 anak stunting dan 53 anak normal) yang diperoleh dari delapan Posyandu di bawah wilayah kerja lima Puskesmas yang terdapat di wilayah Kecamatan Pontianak Timur dan Kecamatan Pontianak Utara. Pengambilan sampel dilakukan secara simple random sampling.

Variabel bebas dalam penelitin ini adalah kadar kalsium serum dan variabel terikat yaitu stunting. Stunting adalah anak usia 24-59 bulan yang tergolong pendek berdasarkan indikator tinggi badan menurut umur (TB/U) menggunakan z-score standar baku WHO 2005, yang dikelompokkan dalam dua kategori yaitu stunting (z-score $<-2$ SD) dan tidak stunting (z-score $\geq-2 \mathrm{SD}$ ) (2). Sementara pemeriksaan kadar kalsium serum total dalam 
darah anak pada saat dilakukan penelitian dilakukan dengan metode fotometrik menggunakan arsenazo III di Unit Laboratorium Kesehatan Provinsi Kalimantan Barat, dinyatakan dalam $\mathrm{mg} / \mathrm{dL}$ dan dikelompokkan dalam dua kategori untuk anak usia 2-12 tahun, yaitu normal (kadar kalsium serum 8,8-10,8 mg/dL) dan tinggi (kadar kalsium serum $>10,8 \mathrm{mg} / \mathrm{dL}$ ) (11).

Sementara variabel luar yang diteliti adalah usia, jenis kelamin, pendidikan orang tua, besar keluarga, tinggi badan orang tua, berat badan lahir, ASI eksklusif, dan asupan energi. Usia anak adalah selisih antara tanggal pengukuran dengan tanggal lahir dalam satuan bulan dan dikelompokkan dalam dua kategori, yaitu 24-47 bulan dan 48-59 bulan. Pendidikan orang tua adalah tingkat pendidikan formal terakhir yang pernah diikuti ayah dan ibu yang dikategorikan menjadi pendidikan rendah ( $<$ SMA) dan tinggi ( $\geq$ SMA). Besar keluarga yaitu jumlah orang atau individu atau anggota keluarga yang tinggal dan menetap dalam satu rumah dan dikategorikan menjadi keluarga kecil ( $\leq 4$ orang) dan keluarga besar ( $>4$ orang). Tinggi badan (TB) ibu dan ayah diukur menggunakan microtoise (ketelitian 0,1 cm) dengan kategori TB ibu yaitu pendek $(<150 \mathrm{~cm})$ dan normal $(\geq 150 \mathrm{~cm}$ ) (12) demikian juga dengan kategori TB ayah yang dikategorikan pendek $(<162 \mathrm{~cm})$ dan normal $(\geq 162$ cm) (13). Berat badan lahir anak diperoleh dari buku Kesehatan Ibu dan Anak (Buku KIA) yang tergolong berat badan lahir rendah (BBLR) jika berat lahir anak kurang dari 2.500 g. Asupan energi diperoleh dari makanan yang dikonsumsi oleh anak melalui metode food recall 24 jam sebanyak enam kali tidak berturut-turut kemudian dianalisis dengan software Nutrisurvey. Asupan energi dikategorikan menjadi dua yaitu cukup ( $\geq 80 \% \mathrm{AKG}$ ) dan rendah $(<80 \% \mathrm{AKG})(14)$.

Analisis univariat dilakukan untuk mengetahui karakteristik dan distribusi data. Analisis bivariat untuk menguji hubungan antara variabel bebas dan variabel terikat dengan uji Chi-Square dan independent samples t-test sedangkan analisis multivariat dengan uji regresi logistik. Pengambilan data dibantu oleh tenaga enumerator dengan kualifikasi DIII kesehatan yaitu tiga orang tenaga gizi untuk melakukan wawancara dan pengukuran antropometri serta dua orang tenaga laboran untuk melakukan pengambilan darah.

\section{HASIL}

Subjek penelitian terdiri dari 37 anak stunting dan 53 anak normal. Sebagian besar berjenis kelamin lakilaki dan berusia 24 sampai 47 bulan. Mayoritas keluarga subjek dikategorikan keluarga besar dan sebagian besar tinggi badan ibu dikategorikan pendek. Rata-rata subjek lahir dengan berat badan normal dan tidak mendapatkan ASI eksklusif (Tabel 1).

Tabel 1. Distribusi karakteristik subjek penelitian

\begin{tabular}{|c|c|c|}
\hline Variabel & $\mathbf{n}$ & $\%$ \\
\hline \multicolumn{3}{|c|}{ Status gizi indikator $\mathrm{TB} / \mathrm{U}$} \\
\hline Sangat pendek & 12 & 13,33 \\
\hline Pendek & 25 & 27,78 \\
\hline Normal & 53 & 58,89 \\
\hline \multicolumn{3}{|l|}{ Usia anak (bulan) } \\
\hline $24-47$ & 64 & 71,11 \\
\hline $48-59$ & 26 & 28,89 \\
\hline \multicolumn{3}{|l|}{ Jenis kelamin anak } \\
\hline Laki-laki & 51 & 56,67 \\
\hline Perempuan & 39 & 43,33 \\
\hline \multicolumn{3}{|l|}{ Pendidikan ayah } \\
\hline Rendah & 52 & 57,78 \\
\hline Tinggi & 38 & 42,22 \\
\hline \multicolumn{3}{|l|}{ Pendidikan ibu } \\
\hline Rendah & 47 & 52,22 \\
\hline Tinggi & 43 & 47,78 \\
\hline \multicolumn{3}{|l|}{ Pekerjaan Ibu } \\
\hline Tidak bekerja & 72 & 80,00 \\
\hline Bekerja & 18 & 20,00 \\
\hline \multicolumn{3}{|l|}{ Besar keluarga } \\
\hline Keluarga besar & 54 & 60,00 \\
\hline Keluarga kecil & 36 & 40,00 \\
\hline \multicolumn{3}{|l|}{ Tinggi badan ibu } \\
\hline Pendek & 34 & 37,78 \\
\hline Normal & 56 & 62,22 \\
\hline \multicolumn{3}{|l|}{ Tinggi badan ayah } \\
\hline Pendek & 23 & 25,56 \\
\hline Normal & 67 & 74,44 \\
\hline \multicolumn{3}{|l|}{ Berat badan lahir } \\
\hline BBLR & 11 & 12,22 \\
\hline Normal & 79 & 87,78 \\
\hline \multicolumn{3}{|l|}{ ASI eksklusif } \\
\hline Tidak & 60 & 66,67 \\
\hline Ya & 30 & 33,33 \\
\hline \multicolumn{3}{|l|}{ Asupan energi } \\
\hline Rendah & 39 & 43,33 \\
\hline Cukup & 51 & 56,67 \\
\hline \multicolumn{3}{|c|}{ Kategori kadar kalsium serum } \\
\hline Tinggi & 65 & 72,22 \\
\hline Normal & 25 & 27,78 \\
\hline
\end{tabular}


Tabel 2. Analisis bivariat perbedaan kadar kalsium serum pada anak stunting dan tidak stunting

\begin{tabular}{|c|c|c|c|c|c|c|c|c|c|}
\hline \multirow{2}{*}{ Variabel } & \multicolumn{2}{|c|}{ Stunting } & \multicolumn{2}{|c|}{ Tidak stunting } & \multicolumn{2}{|c|}{ Total } & \multirow{2}{*}{ PR } & \multirow{2}{*}{$95 \%$ CI } & \multirow{2}{*}{$\mathbf{p}$} \\
\hline & $\mathbf{n}$ & $\%$ & $\mathbf{n}$ & $\%$ & $\mathbf{n}$ & $\%$ & & & \\
\hline \multicolumn{10}{|c|}{ Kadar kalsium serum } \\
\hline Tinggi & 24 & 64,86 & 41 & 77,36 & 65 & 72,22 & \multirow{2}{*}{0,71} & \multirow{2}{*}{$-0,38-0,08$} & \multirow{2}{*}{0,193} \\
\hline Normal & 13 & 35,14 & 12 & 22,64 & 25 & 27,78 & & & \\
\hline
\end{tabular}

Tabel 3. Analisis bivariat antara variabel luar pada anak stunting dan tidak stunting

\begin{tabular}{|c|c|c|c|c|c|c|c|c|c|}
\hline \multirow{2}{*}{ Variabel } & \multicolumn{2}{|c|}{ Stunting } & \multicolumn{2}{|c|}{ Tidak stunting } & \multicolumn{2}{|c|}{ Total } & \multirow{2}{*}{ PR } & \multirow{2}{*}{$95 \% \mathrm{CI}$} & \multirow{2}{*}{$\mathbf{p}$} \\
\hline & $\mathbf{n}$ & $\%$ & $\mathbf{n}$ & $\%$ & $\mathbf{n}$ & $\%$ & & & \\
\hline \multicolumn{10}{|l|}{ Usia anak (bulan) } \\
\hline $24-47$ & 28 & 75,68 & 36 & 67,92 & 64 & 71,11 & \multirow{2}{*}{1,25} & \multirow{2}{*}{$-0,11-0,27$} & \multirow{2}{*}{0,425} \\
\hline $48-59$ & 9 & 24,32 & 17 & 32,08 & 26 & 28,89 & & & \\
\hline \multicolumn{10}{|l|}{ Jenis kelamin } \\
\hline Laki-laki & 21 & 56,76 & 30 & 56,60 & 51 & 56,67 & \multirow[b]{2}{*}{1,00} & \multirow{2}{*}{$\begin{array}{c}-0,21- \\
0,21\end{array}$} & \multirow{2}{*}{0,989} \\
\hline Perempuan & 16 & 43,24 & 23 & 43,40 & 39 & 43,33 & & & \\
\hline \multicolumn{10}{|l|}{ Pendidikan ayah } \\
\hline Rendah & 24 & 64,86 & 28 & 52,83 & 52 & 57,78 & \multirow{2}{*}{1,35} & \multirow{2}{*}{$-0,09-0,33$} & \multirow{2}{*}{0,255} \\
\hline Tinggi & 13 & 35,14 & 25 & 47,17 & 38 & 42,22 & & & \\
\hline \multicolumn{10}{|l|}{ Pendidikan ibu } \\
\hline Rendah & 21 & 56,76 & 26 & 49,06 & 47 & 52,22 & \multirow{2}{*}{0,17} & \multirow{2}{*}{$-0,13-0,29$} & \multirow{2}{*}{0,472} \\
\hline Tinggi & 16 & 43,24 & 27 & 50,94 & 43 & 47,78 & & & \\
\hline \multicolumn{10}{|l|}{ Besar keluarga } \\
\hline Keluarga besar & 27 & 72,97 & 27 & 50,94 & 54 & 60,00 & \multirow{2}{*}{1,80} & \multirow{2}{*}{$0,02-0,42$} & \multirow{2}{*}{0,036} \\
\hline Keluarga kecil & 10 & 27,03 & 26 & 49,06 & 36 & 40,00 & & & \\
\hline \multicolumn{10}{|l|}{ Tinggi badan ibu } \\
\hline Pendek & 22 & 59,46 & 12 & 22,64 & 34 & 37,78 & & & \\
\hline Normal & 15 & 40,54 & 41 & 77,36 & 56 & 62,22 & 2,41 & $0,17-0,56$ & 0,000 \\
\hline Tinggi badan ayah & & & & & & & & & \\
\hline Pendek & 15 & 40,54 & 8 & 15,09 & 23 & 25,56 & & & \\
\hline Normal & 22 & 59,46 & 45 & 84,91 & 67 & 74,44 & 1,99 & $0,08-0,43$ & 0,005 \\
\hline Berat badan lahir & & & & & & & & & \\
\hline BBLR & 5 & 13,51 & 6 & 11,32 & 11 & 12,22 & 112 & $012-016$ & 0750 \\
\hline Normal & 32 & 86,49 & 47 & 88,68 & 79 & 87,78 & 1,12 & $-0,12-0,16$ & 0,750 \\
\hline ASI eksklusif & & & & & & & & & \\
\hline Tidak & 24 & 64,86 & 36 & 67,92 & 60 & 66,67 & & & \\
\hline Ya & 13 & 35,14 & 17 & 32,08 & 30 & 33,33 & 0,92 & $-0,23-0,17$ & 0,762 \\
\hline Asupan energi & & & & & & & & & \\
\hline Rendah & 25 & 65,57 & 14 & 26,42 & 39 & 43,33 & & & 0000 \\
\hline Cukup & 12 & 32,43 & 39 & 73,58 & 51 & 56,67 & $2, / 8$ & $0,22-0,60$ & 0,000 \\
\hline
\end{tabular}

Hasil penelitian menunjukkan sebagian besar kadar kalsium serum pada subjek dikategorikan tinggi. Berdasarkan analisis bivariat diketahui bahwa tidak ada perbedaan yang bermakna antara kadar kalsium serum pada anak stunting dan tidak stunting $(\mathrm{p}>0,05)$. Ratarata kadar kalsium serum pada anak stunting sebesar $12,14 \pm 1,97 \mathrm{mg} / \mathrm{dL}$ sedangkan pada anak tidak stunting sebesar 12,16 $\pm 1,63 \mathrm{mg} / \mathrm{dL}$, hasil uji t menunjukkan bahwa tidak ada perberbedaan yang bermakna $(\mathrm{p}>0,05)$ (Tabel 2).

Hasil analisis bivariat menunjukkan bahwa tidak ada perbedaan yang bermakna antara usia, jenis kelamin, pendidikan orang tua, berat badan lahir, dan pemberian ASI eksklusif pada anak stunting dan tidak stunting ( $\mathrm{p}>0,05)$. Besar keluarga, tinggi badan orang tua, dan kategori asupan energi pada kelompok anak stunting 
Tabel 4. Analisis multivariat variabel bebas dan variabel luar terhadap kejadian stunting

\begin{tabular}{lcccc}
\hline Variabel & SE & p & OR & 95\% CI \\
\hline Model 1 & & & & \\
Kadar kalsium serum & 0,57 & 0,40 & 0,48 & $-0,65-1,61$ \\
Besar keluarga & 0,55 & 0,69 & 0,22 & $-1,31-0,87$ \\
Tinggi badan ibu & 0,52 & $0,00 *$ & 1,43 & $0,40-2,46$ \\
Tinggi badan ayah & 0,58 & 0,41 & 1,19 & $0,49-2,33$ \\
Asupan energi & 0,57 & 0,40 & 0,48 & $0,41-2,46$ \\
\hline Model 2 & & & & \\
Kadar kalsium serum & 0,57 & 0,39 & 0,49 & $-0,64-1,61$ \\
Tinggi badan ibu & 0,52 & $0,00 *$ & 1,46 & $0,44-2,48$ \\
Tinggi badan ayah & 0,58 & $0,03 *$ & 1,22 & $0,09-2,35$ \\
Asupan energi & 0,51 & $0,00 *$ & 1,52 & $0,51-2,52$ \\
\hline Model 3 & & & & \\
Tinggi badan ibu & 0,52 & $0,00 *$ & 1,46 & $0,44-2,48$ \\
Tinggi badan ayah & 0,57 & $0,02 *$ & 1,28 & $0,17-2,40$ \\
Asupan energi & 0,51 & $0,00 *$ & 1,52 & $0,52-2,52$ \\
\hline
\end{tabular}

Deviance $(-2$ log likelihood $)=92,89$

$\mathrm{R}^{2}=0,2380$

*bermakna $(\mathrm{p}<0,05)$

dan tidak stunting memiliki perbedaan yang bermakna $(\mathrm{p}<0,05)$. Hasil uji $t$ test menunjukkan rerata asupan energi pada anak stunting lebih redah dibandingkan asupan energi pada anak tidak stunting, yaitu $896 \pm 227$ kcal dan $1.212 \pm 387 \mathrm{kcal}$ dengan perbedaan yang bermakna ( $\mathrm{p}=0,000)$ (Tabel 3).

Hasil analisis multivariat pada Tabel 4 menunjukkan variabel besar keluarga dan kadar kalsium serum menjadi tidak bermakna setelah dilakukan kontrol terhadap variabel luar. Variabel tinggi badan ibu, tinggi badan ayah, dan asupan energi tetap bermakna terhadap kejadian stunting.

\section{BAHASAN}

Hasil analisis bivariat menunjukkan bahwa tidak ada perbedaan yang bermakna antara kadar kalsium serum pada anak stunting dan tidak stunting. Tidak adanya perbedaan yang bermakna tersebut menunjukkan bahwa tubuh selalu mempertahankan kadar kalsium serum dalam rentang yang sempit. Kalsium pada tubuh manusia berada dalam kontrol homeostasis oleh tiga organ utama yaitu tulang, ginjal, dan sistem gastrointestinal serta fisiologi dari PTH, kalsitonin, dan vitamin D $(15,16)$. Kalsium serum dipertahankan sebagai regulator pada berbagai proses sel, termasuk dalam mineralisasi tulang, kontraksi otot, aktivitas enzim, eksitabilitas membran, dan perantara intrasel efek hormon $(9,17,18)$. Keadaan inilah yang menyebabkan rerata kadar kalsium serum tidak berbeda secara bermakna pada anak stunting dan tidak stunting.

Hasil penelitian ini menunjukkan bahwa kadar kalsium serum pada anak-anak dikategorikan normal dan tinggi, tidak terdapat subjek dengan kategori kadar kalsium serum yang rendah. Meskipun demikian, secara klinis belum ada tanda-tanda hiperkalsemia. Pada beberapa literatur, dikatakan bahwa konsentrasi total kalsium serum yang lebih dari $12-15 \mathrm{mg} / \mathrm{dL}$ tidak terkait dengan tanda-tanda sistemik, tetapi konsentrasi serum lebih dari $18 \mathrm{mg} / \mathrm{dL}$ sering dikaitkan dengan tanda-tanda berat yang mengancam jiwa dalam keadaan akut $(18,19)$.

Penambahan massa mineral tulang pada masa anak-anak dipengaruhi oleh banyak faktor termasuk genetik, jenis kelamin, kalsium dan protein, aktivitas fisik, status endokrin (hormon paratiroid, vitamin D, kalsitonin, dan insulin-like growth factor) (20). Rerata kadar kalsium serum pada subjek dalam penelitian ini tergolong tinggi, tetapi proses pertumbuhan tulang tidak terlepas dari adanya sintesis protein dan hormon. Pada masa pertumbuhan, tubuh memanfaatkan kalsium dalam darah untuk proses metabolisme dan sintesis protein. Kalsium dalam hal ini berperan penting dalam sekresi hormon, aktivitas enzim kunci dan protein dependen kalsium (17). Penjelasan mengenai kadar kalsium serum yang tinggi di lokasi penelitian ini disebabkan oleh tingginya paparan sinar matahari. Kota Pontianak merupakan salah satu daerah tropis dengan suhu udara cukup tinggi serta diiringi kelembaban yang tinggi. Selain itu, Kota Pontianak terletak di lintasan garis khatulistiwa sehingga terdapat sejumlah besar paparan sinar matahari. Rata-rata suhu di Kota Pontianak mencapai $28-34^{\circ} \mathrm{C}$ dengan kelembaban udara 86-92\% dan lama penyinaran matahari 34-78\% (21).

Vitamin $\mathrm{D}_{3}$ dibuat di dalam kulit dari 7-dehidrokolesterol dengan proses non-enzimatis, berkataliskan energi cahaya ultraviolet (UV) yang membutuhkan pravitamin (18). Ketika sinar matahari berlimpah, serum 25-hidroksikolekalsiferol yang relatif 
tinggi menyebabkan kadar kalsium serum yang lebih tinggi. Sinar UV sangat penting dalam reaksi ini. Di dalam ginjal dirangsang oleh $1 \alpha$-hidroksilase, enzim yang mengubah 25-hidroksikolekalsiferol menjadi 1,25-dihidroksikolekalsiferol atau $1,25(\mathrm{OH})_{2} \mathrm{D}_{3}$. Bentuk $1,25(\mathrm{OH})_{2} \mathrm{D}_{3}$ adalah bentuk aktif dari vitamin $\mathrm{D}$ dan meningkatnya sintesis $1,25(\mathrm{OH})_{2} \mathrm{D}_{3}$ lebih lanjut dapat berkontribusi terhadap peningkatan kadar kalsium serum $(22,23)$. Hasil penelitian ini sesuai dengan penelitian sebelumnya yang dilakukan di Malaysia, yang menemukan kejadian hiperkalsiemia pada 27,5\% subjek yang baru didiagnosis tuberkulosis. Malaysia terletak tepat di atas garis khatulistiwa dengan sinar matahari berlimpah sepanjang tahun, hal ini menjelaskan relatif tingginya insiden hiperkalsemia pada subjek penelitian (24).

Pada penelitian ini, rerata kadar kalsium dalam darah pada kedua kelompok tergolong tinggi, meskipun asupan kalsium pada anak stunting tergolong rendah dan asupan kalsium pada anak tidak stunting tergolong cukup. Dalam upaya mempertahankan kondisi yang sehat, tulang harus mendapatkan asupan kalsium dan vitamin D yang memadai sepanjang hidup. Meskipun kadar kalsium dalam darah tergolong tinggi, tetapi asupan kalsium pada anak hendaknya ditingkatkan hingga mencukupi kebutuhan karena pada kondisi tersebut terjadi pengeluaran kalsium dari tulang ke cairan ekstraselular sehingga kekurangan asupan kalsium dapat mengakibatkan penurunan massa tulang atau osteopenia (9). Lebih lanjut, diketahui bahwa terdapat dua bentuk kalsium yang dapat diperiksa yaitu kalsium total dan kalsium ion. Analisis kalsium serum pada penelitian ini menggunakan kalsium total, sebaiknya menggunakan pengukuran kalsium ion karena yang memiliki peran spesifik dalam proses pembentukan tulang adalah kalsium ion.

Hasil penelitian menunjukkan bahwa anak stunting lebih banyak ditemukan pada kategori umur 24-47 bulan. Kondisi ini disebabkan oleh tingginya kebutuhan zat gizi pada anak usia dua sampai tiga tahun, dalam hubungan dengan tinggi atau panjang badannya dibanding usiausia berikutnya. Pada usia tersebut, laju pertumbuhan mencapai puncak atau tercepat sehingga membutuhkan banyak zat gizi. Pertumbuhan anak semakin menyimpang dari normal dengan bertambahnya umur jika ketersediaan makanan tidak memadai. Sebagian besar anak stunting berasal dari keluarga dengan tingkat pendidikan ayah dan ibu yang rendah. Pendidikan orang tua merupakan unsur penting yang dapat mempengaruhi keadaan gizi keluarga karena tingkat pendidikan yang lebih tinggi dapat membantu pembentukan konsep hubungan antara pola makan dan kesehatan (25). Di samping itu, kategori besar keluarga pada anak stunting dan tidak stunting memiliki perbedaan yang bermakna $(\mathrm{p}=0,036)$. Jumlah anggota keluarga yang semakin besar tanpa diimbangi dengan meningkatnya pendapatan akan menyebabkan semakin tidak meratanya pendistribusian konsumsi pangan. Pangan yang tersedia untuk suatu keluarga besar mungkin hanya cukup untuk keluarga yang besarnya setengah dari keluarga tersebut. Keadaaan yang demikian tidak cukup untuk mencegah timbulnya gangguan gizi pada keluarga besar.

Tinggi badan orang tua pada kedua kelompok menunjukkan perbedaan yang bermakna. Sebesar 60$80 \%$ peak bone mass dipengaruhi oleh faktor genetik dan selebihnya dapat digunakan untuk intervensi yang bertujuan untuk memaksimalkan peak bone mass (20). Hasil Demographic and Health Surveys menunjukkan terdapat hubungan yang bermakna antara tinggi badan ibu dan kejadian stunting di 52 dari 54 negara (96\%) yang dianalisis (26). Tinggi badan ibu yang rendah berkaitan dengan peningkatan risiko underweight dan stunting pada keturunannya (27). Kedua orang tua yang tergolong pendek cenderung memiliki anak-anak stunting begitu pula sebaliknya, pada orang tua dengan tinggi badan normal maka anak-anak akan tumbuh dengan normal (28).

Hasil penelitian juga menunjukkan tidak adanya perbedaan yang bermakna antara berat badan lahir pada kedua kelompok dan hanya 11 subjek yang diketahui lahir dengan berat badan lahir rendah. Berat badan lahir rendah adalah prediktor bermakna dari kejadian stunting dan underweight pada anak usia 12 bulan dan underweight pada anak usia enam bulan (29). Demikian juga dengan ASI eksklusif yang menunjukkan tidak adanya perbedaan yang bermakna antara pemberian ASI eksklusif pada kedua kelompok. Sebagian besar anak stunting diperkenalkan dengan makanan pendamping-air susu ibu (MP-ASI) saat usia enam bulan dan sebagian 
besar anak normal diperkenalkan dengan MP-ASI saat usia kurang dari enam bulan.

Lebih lanjut, rerata asupan energi menunjukkan perbedaan yang bermakna antara kedua kelompok. Energi berfungsi sebagai zat tenaga untuk metabolisme, pertumbuhan, pengaturan suhu, dan kegiatan fisik. Selama masa pertumbuhan, asupan zat gizi secara terus menerus diperlukan untuk menyokong aktivitas sel tulang dalam pembentukan dan mempertahankan jaringan tulang (18). Sejalan dengan beberapa penelitian sebelumnya bahwa asupan energi dan kejadian stunting menunjukkan hubungan yang bermakna pada balita di Kalimantan Barat, Kabupaten Maluku, dan Kabupaten Bogor (30-32). Konsumsi energi yang kurang dari 85\% AKG mempunyai peluang risiko stunting 1,37 kali pada balita di Kalimantan Barat (31).

Hasil analisis multivariat menunjukkan bahwa tinggi badan ibu, tinggi badan ayah, dan asupan energi merupakan faktor risiko yang paling menentukan kejadian stunting pada anak. Tinggi badan orang tua merupakan salah satu faktor risiko utama kejadian stunting pada anak (33). Hasil penelitian di Kabupaten Bogor melaporkan bahwa semakin tinggi tingkat kecukupan energi, semakin baik status gizi balita. Setiap penambahan satu persen tingkat kecukupan energi balita, akan menambah $z$-score TB/U balita sebesar 0,032 satuan (34).

\section{SIMPULAN DAN SARAN}

Tidak ada perbedaan yang bermakna antara kadar kalsium serum pada anak stunting dan tidak stunting usia 24-59 bulan di Kota Pontianak. Perlu dilakukan pengukuran tinggi badan secara teratur sebagai salah satu cara deteksi dini stunting dan perlu kerjasama antar stakeholders untuk membentuk tim khusus dalam menangani masalah stunting. Perlu dilakukan penelitian lebih lanjut mengenai penyebab kadar kalsium serum yang tergolong tinggi pada anak-anak yang tinggal di wilayah tropis.

\section{RUJUKAN}

1. McDonald CM, Manji KP, Kupka R, Bellinger DC, Spiegelman D, Kisenge R. Stunting and wasting are associated with poorer psychomotor and mental development in HIV-exposed tanzanian infants. J Nutr 2013;143(2):204-14.

2. World Health Organization. Nutrition landscape information system (NLIS) country profile indicators: interpretation guide. Geneva: WHO; 2010.

3. World Health Assembly. Global nutrition targets 2025: Stunting policy brief. Geneva: WHO; 2014.

4. Kementerian Kesehatan Republik Indonesia. Laporan hasil Riset Kesehatan Dasar (Riskesdas) tahun 2013. Jakarta: Kemenkes; 2013.

5. Fikadu T, Assegid A, Dube L. Factors associated with stunting among children of age 24-59 months in Meskan District, Gurage Zone, South Ethiopia: a casecontrol study. BMC Public Health 2014;14:800-6.

6. Senbanjo IO, Oshikoya KA, Odusanya OO, Njokanma OF. Prevalence of and risk factor for stunting among school children and adolescents in Abeokuta, Southwest Nigeria. J Health Popul Nutr 2011;29(4):364-70.

7. Khairy SAM, Mattar MK, Refaat LAM, ElSherbeny SA. Plasma micronutrient levels of stunted Egyptian School age children. Kasr El Aini Med J 2010;16(1):1-5.

8. Prentice A, Dibba B, Sawo Y, Cole TJ. The effect of prepubertal calcium carbonate supplementation on the age of peak height velocity in Gambian Adolescents. Am J Clin Nutr 2012;96(5):1042-50.

9. Peacock M. Calcium metabolism in health and disease. Clin J Am Soc Nephrol 2010; 5:S23-30.

10. Sloane E. Anatomi dan fisiologi untuk pemula. Jakarta: EGC; 2003.

11. Lee CT, Yang CC, Lam KK, Kung CT, Tsai CJ, Chen HC. Hypercalcemia in the emergency department. Am J Med Sci 2006;331(3):119-23.

12. Jahari AB. Median berat badan dan tinggi badan normal orang Indonesia berdasarkan data Riskesdas 2007 dan 2010. Dalam: Widya Karya Nasional Pangan dan Gizi X. Jakarta: LIPI; 2012.

13. Muhilal, Hardinsyah. Penentuan kebutuhan gizi dan kesepakatan harmonisasi di Asia Tenggara. Dalam: Ketahanan pangan dan gizi di era otonomi daerah dan globalisasi. Prosiding Widya Karya Nasional Pangan dan Gizi VIII; 2004; Jakarta. 
14. Candra A, Puruhita N, Susanto JC. Risk factors of stunting among 1-2 years old children in Semarang City. M Med Indonesiana 2011;45(3):206-12.

15. Baird GS. Ionized calcium. Clin Chim Acta 2011;412(9-10):696-701.

16. Brown EM. Role of the calcium-sensing receptor in extracellular calcium homeostasis. Best Pract Res Clin Endocrinol Metab 2013;27(3):333-43.

17. Murray RK, Granner DK, Rodwell VW. Biokimia harper, Ed. 27. Jakarta: EGC; 2009.

18. Linder MC. Biokimia nutrisi dan metabolisme. Jakarta: UI Press; 2010.

19. Cline J. Calcium and vitamin D metabolism, deficiency, and excess. Top Companion Anim Med 2012;27(4):159-64.

20. Burckhardt P, Hughes BD, Weaver C. Nutritional influences on bone health. New York: Springer; 2010.

21. Badan Pusat Statistik Kota Pontianak. Profil daerah Kota Pontianak. Pontianak: BPS; 2014.

22. Amare B, Moges B, Fantahun B, Tafess K, Woldeyohannes D, Yismaw G, et al. Micronutrient levels and nutritional status of school children living in Northwest Ethiopia. Nutr J 2012;11:108-16.

23. Nolla NP, Sop MMK, Mananga MJ, Ekoue T, Goiado I. Assessment of nutritional status of preschool children in the Bangang Rural Community, Cameroon. Int J Biotechnol Food Sci 2014;2(2):44-52.

24. Liam CK, Lim KH, Srinivas P, Poi PJH. Hypercalcaemia in patients with newly diagnosed tuberculosis in Malaysia. Int J Tuberc Lung Dis 1998;2(10):818-23.

25. Gibney MJ, Margaretts BM, Kearney JM, Arab L. Gizi kesehatan masyarakat. Jakarta: EGC; 2009.

26. Ozaltin E, Hill K, Subramanian SV. Association of maternal stature with offspring mortality, underweight, and stunting in low to middle income countries. JAMA 2010;303(15):1507-16.

27. Dewey KG, Begum K. Long-term consequences of stunting in early life. Matern Child Nutr 2011;7(3):518.

28. Wahdah S. Faktor risiko kejadian stunting pada anak umur 6-36 bulan di wilayah pedalaman Kecamatan Silat Hulu Kabupaten Kapuas Hulu Provinsi Kalimantan Barat [Tesis]. Yogyakarta: Universitas Gadjah Mada; 2012.

29. Medhin G, Hanlon C, Dewey M, Alem A, Tesfaye F, Prince $\mathrm{M}$, et al. Prevalence and predictors of undernutrition among infants aged six and twelve months in Butajira, Ethiopia: the P-MaMiE birth cohort. BMC Public Health 2010;10(27):1-15.

30. Asrar M, Hadi H, Boediman D. Hubungan pola asuh, pola makan, asupan zat gizi dengan status gizi anak balita masyarakat Suku Naulu di Kecamatan Amahai Kabupaten Maluku Tengah Propinsi Maluku. Jurnal Gizi Klinik Indonesia 2009;6(2):84-94.

31. Damanik MR, Ekayanti I, Hariyadi D. Analisis pengaruh pendidikan ibu terhadap status gizi balita di Provinsi Kalimantan Barat. J Gizi Pangan 2010;5(2):69-77.

32. Astari LD, Nasoetion A, Dwiriani CM. Hubungan karakteristik keluarga, pola pengasuhan, dan kejadian stunting anak usia 6-12 bulan. Mediagizi 2005;29(2):40-6.

33. Amigo $\mathrm{H}$, Bustos $\mathrm{P}$, Leone $\mathrm{C}$, Radrigan ME. Growth deficits in Chilean school children. J Nutr 2010;131(2):251-54.

34. Solihin RDM, Anwar F, Sukandar, D. Kaitan antara status gizi, perkembangan kognitif, dan perkembangan motorik pada anak usia prasekolah. PGM 2013;36(1):62-72. 